\title{
SELF MANAGEMENT TERHADAP PSYCHOSOCIAL ADJUSTMENT PASIEN PENYAKIT GINJAL KRONIS DENGAN HEMODIALISA
}

\author{
Astuti ${ }^{1}$, Anggorowati ${ }^{2}$ Kusuma $^{3}$ \\ ${ }^{1}$ Mahasiswa Prodi Magister Keperawatan, Universitas Diponegoro \\ 2 Dosen Prodi Magister Keperawatan, Universitas Diponegoro \\ email: astutidwi20@yahoo.co.id
}

\begin{abstract}
Patients with chronic kidney disease should take regular hemodialysis therapy. The main cause of the deterioration of the psychosocial state of the patients undergoing hemodialysis is the failure to adapt to the current state of illness. Objective of this study is to investigate the effect of self-management (education and SEFT therapy) towards psychosocial adjustment in patients with chronic kidney disease undergoing hemodialysis. The method used is quasi experiment with pre-test and post-test control group design. This study used purposive sampling with 32 patients with chronic kidney disease. The treatment provided is self-management with education and SEFT therapy in respondent at the hospital. The data collection used is questionnaire Pasychosocial Adjustment to IIIness Scale (PAIS). Result of research showed that the ability of psychosocial adjustment patients on pre-test (x) PAIS: 103,12 and post test (x) PAIS: 141,81. Based on the results of wilcoxon test obtained $p$ value 0,000 , the hypothesis of this study is accepted. The ability of psychosocial adjustment of patients increases after participating educational treatment and SEFT therapy. The engagement between patient, family and nurse can improve the patient's psychosocial adjustment as respond the changes in health status.
\end{abstract}

Keywords: hemodialysis, kidney, psychosocial, therapy

\section{ABSTRAK}

Pasien dengan penyakit ginjal kronik harus menjalani terapi hemodialisa secara rutin. Salah satu penyebab terpuruknya keadaan psikososial klien adalah gagalnya beradaptasi dengan keadaan sakitnya saat ini. Tujuan penelitian untuk mengetahui pengaruh self management (edukasi dan SEFT therapy) terhadap psychososial adjusment pada pasien dengan penyakit ginjal kronik yang menjalani hemodialisa. Metode yang dilakukan adalah quasi eksperimen dengan rancangan pre-test and post-test with control group design. Sampel dipilih menggunakan teknik purposive sampling sebanyak 32 pasien penyakit ginjal kronis. Perlakuan yang diberikan adalah self management dengan edukasi dan SEFT therapy pada responden saat di rumah sakit. Pengambilan data dengan menggunakan kuesioner Psychosocial Adjustment to IIness Scale (PAIS). Hasil penelitian menunjukkan kemampuan psychosocial adjustment responden pada pre-test (x) PAIS: 103,12 dan post-test (x) PAIS: 141,81. Berdasarkan hasil wilcoxon test didapatkan $p$ value 0,000 maka hipotesa penelitian ini diterima. Kemampuan psychosocial adjusment pasien penyakit ginjal kronis meningkat setelah diberikan perlakuan edukasi dan SEFT therapy. Keterlibatan secara aktif antara pasien, keluarga dan perawat dapat meningkatkan kemampuan adaptasi psikososial pasien terhadap perubahan status kesehatannya.

Kata kunci: ginjal, hemodialisa, psikososial, terapi 


\section{PENDAHULUAN}

Penyakit ginjal kronik merupakan suatu kegagalan fungsi ginjal untuk mempertahankan metabolisme serta keseimbangan cairan dan elektrolit akibat destruksi struktur ginjal yang progresif dengan manifestasi penumpukan sisa metabolit (toksit uremik) di dalam darah (Muttaqin, 2009). Kidney Disease Improving Global Outcome (KDIGO) mendefinisikan penyakit ginjal kronik sebagai kerusakan ginjal lebih dari tiga bulan dengan kelainan ginjal secara struktural atau fungsional dengan atau tanpa penurunan laju filtrasi glomerulus (GFR) atau GFR $<60 \mathrm{ml} / \mathrm{min} / 1.73 \mathrm{~m} 2$ (Smart et al., 2013). Fungsi ginjal menurun secara menetap akibat kerusakan nefron yang berjalan secara kronis, progresif dan bersifat irreversible. Kondisi ini mengakibatkan tubuh gagal mempertahankan metabolisme serta keseimbangan cairan dan elektrolit yang menyebabkan azotemia (retensi urea dan sampah nitrogen lain dalam darah) (Smeltzer, 2015 dan Syamsir, 2008).

Penyakit ginjal kronik berkaitan erat dengan proses degeneratif sebagai akibat dari kemunduran atau kerusakan fungsi organ-organ tubuh. Penyakit degeneratif yang berhubungan dengan meningkatnya kejadian penyakit ginjal kronik antara lain diabetes mellitus, hipertensi, penyakit jantung koroner, dan penyakit metabolik lainnya yang dapat menyebabkan penurunan fungsi ginjal (PERNEFRI, 2003). Selain penyakit degeneratif, gaya hidup tidak sehat, budaya, dan perubahan status sosial ekonomi juga memberikan dampak terhadap peningkatan angka kejadian penyakit ginjal kronis (PERNEFRI, 2003).

World Health Organization memaparkan bahwa dari tahun 2009 sampai tahun 2011 sebanyak 36 juta orang warga dunia meninggal dunia akibat penyakit ginjal kronis. Indonesia termasuk negara dengan tingkat penderita gagal ginjal yang cukup tinggi. Yayasan Ginjal Diatrans Indonesia (YGDI) menyatakan bahwa pada tahun 2006, diperkirakan jumlah pasien PGK di Indonesia sebanyak 150.000 orang. Dari jumlah tersebut $21 \%$ berusia $15-34$ tahun, $49 \%$ berusia $35-55$ tahun, dan $30 \%$ berusia diatas 56 tahun (Smeltzer \& Bare, 2002). Persatuan Nefrologi Indonesia memperkirakan pada tahun 2015 sebanyak 70 ribu orang mengalami gagal ginjal (Nurani \& Mariyanti, 2002).

Proses hemodialisis sangat membantu penderita penyakit ginjal kronik, khususnya tahap terminal karena kondisi nefron hanya 15\% yang berfungsi (gagal ginjal terminal atau tahap akhir) (Smeltzer \& Bare, 2002). Proses hemodialisis dilakukan sebagai upaya untuk memperpanjang usia penderita. Proses ini membantu penderita mengembalikan fungsi ginjal yang sudah rusak, akan tetapi meningkatkan kesejahteraan kehidupan pasien dengan gagal ginjal kronik (Smeltzer \& Bare, 2002). Meskipun fungsi ginjal untuk membersihkan darah dapat digantikan oleh mesin hemodialisis, tetapi proses tersebut menimbulkan masalah kesehatan bagi pasien. Ketergantungan pada mesin hemodialisis, juga menimbulkan masalah baik fisik, psikologis, maupun sosial yang dirasakan sebagai beban bagi penderitanya (Nurani \& Mariyanti, 2002).

$$
\text { Salah satu penyebab }
$$

terpuruknya keadaan psikososial klien dengan penyakit ginjal kronik yang menjalani hemodialisis adalah gagalnya beradaptasi dengan keadaannya saat ini (Morton, Fontain, Hudak \& Gallo, 2009). Tingkat penyesuaian diri individu dapat 
dikategorikan ke dalam penyesuaian diri yang berhasil (well-adjusted) dan penyesuaian diri yang gagal (maladjusted) (Calhoun \& Cocela, 1990). Individu dengan penyesuaian dirinya baik ialah individu yang mampu mengatasi konflik, frustasi, dan menyelesaikan kesulitan dalam diri maupun kesulitan yang berhubungan dengan lingkungan. Individu dikatakan gagal penyesuaian diri apabila tidak mampu mengatasi konflik yang dihadapi atau tidak menemukan cara-cara yang tepat untuk mengatasi masalah/tuntutan lingkungannya yang disebut reaksi frustasi. Reaksi frustasi ini akan melemahkan fungsi penyesuaian diri yang dapat mengganggu efektivitas penyesuaian diri individu. Penyesuaian diri yang tidak berhasil (mal-adjustment) terjadi karena kondisi tertekan yang mengakibatkan individu bertindak tidak rasional dan tidak efektif, serta mendorong individu melakukan usaha yang tidak realistis untuk menyelesaikan masalah yang dihadapinya (Chen, Tsai, Sun, $\mathrm{Wu}$, Lee \& Wu, 2010).

Self management merupakan salah satu intervensi yang dapat dilakukan perawat untuk meningkatkan status kesehatan pasien dengan kondisi kronis dengan cara berkolaborasi dengan pasien dan keluarganya (Chen, Tsai, Sun, Wu, Lee \& Wu, 2010). Self management merupakan prosedur pembelajaran bagi pasien untuk membedakan target perilaku dan mencatat tercapai atau tidaknya target perilaku tersebut. Self management berarti mendorong diri sendiri untuk maju, mengatur semua unsur kemampuan pribadi, mengendalikan kemampuan untuk mencapai hal-hal yang baik, dan mengembangkan berbagai segi dari kehidupan pribadi pasien agar lebih baik (Schena, 2011).

\section{METODE PENELITIAN}

Penelitian ini menggunakan rancangan quasi experimental with control group design. Populasi pada penelitian ini adalah pasien penyakit ginjal kronik yang menjalani hemodialisis di RSUD Banyumas sejumlah 214 pasien pada periode Januari-Maret 2017. Pemilihan sampel menggunakan teknik purposive sampling berdasarkan kriteria inklusi yang telah ditetapkan, sebanyak 32 pasien ginjal kronik. Kelompok intervensi sejumlah 16 responden menjalani terapi self management yaitu edukasi tentang penyakit ginjal kronis (PGK) dan teknik SEFT selama 8 minggu. Kelompok kontrol diberikan edukasi berdasarkan SOP pelayanan pasien yang menjalani hemodialisis. Pengukuran dilakukan dengan menggunakan kuesioner Psychosocial Adjustment IIIness Scale (PAIS).

Data yang terkumpul dianalisis dan ditampilkan dalam bentuk distribusi frekuensi. Berdasarkan uji normalitas shapiro wilk didapatkan hasil $p=0,000$ sehingga didapatkan kesimpulan distribusi data tidak normal karena nilai $p$ $<0,05$. Maka, kategori Psychosocial Adjustment IIIness Scale menggunakan median sebagai ukuran pemusatan dan minimum-maksimum sebagai ukuran penyebaran. Selanjutnya, dilakukan uji wilcoxon test untuk mengetahui pengaruh self management terhadap psychosocial adjustment pasien penyakit ginjal kronis.

\section{HASIL}

Selama proses pengambilan data, tingkat partisipasi responden sangat baik. Partisipasi responden terlihat dari tidak diperolehnya responden yang drop out selama proses terapi self management. 
Tabel 1. Karakteristik pasien penyakit ginjal kronis di ruang hemodialisa RSUD Banyumas.

\begin{tabular}{|c|c|c|c|c|}
\hline \multirow{3}{*}{ Variabel } & \multicolumn{4}{|c|}{ Kelompok } \\
\hline & \multicolumn{2}{|c|}{ Intervensi } & \multicolumn{2}{|c|}{ Kontrol } \\
\hline & $\mathrm{n}$ & $(\%)$ & $\mathrm{n}$ & $(\%)$ \\
\hline $\begin{array}{l}\text { Usia } \\
15-20 \text { Tahun }\end{array}$ & 4 & 25 & 1 & 6,2 \\
\hline 21 - 25 Tahun & 0 & 0 & 0 & 0 \\
\hline $26-30$ Tahun & 0 & 0 & 0 & 0 \\
\hline 31 - 35 Tahun & 1 & 6,2 & 1 & 6,2 \\
\hline 36 - 40 Tahun & 3 & 18,8 & 2 & 12,6 \\
\hline$>41$ Tahun & 8 & 50 & 12 & 75 \\
\hline \multicolumn{5}{|l|}{ Pendidikan } \\
\hline Tamat SD & 6 & 37,5 & 8 & 50 \\
\hline Tamat SLTP & 2 & 12,5 & 3 & 18,8 \\
\hline Tamat SLTA & 6 & 37,5 & 1 & 6,2 \\
\hline PT & 2 & 12,5 & 4 & 25 \\
\hline \multicolumn{5}{|l|}{ Jenis Kelamin } \\
\hline Pria & 11 & 68,8 & 11 & 68,8 \\
\hline Perempuan & 5 & 31,2 & 5 & 31,2 \\
\hline \multicolumn{5}{|l|}{$\begin{array}{l}\text { Status } \\
\text { Pernikahan }\end{array}$} \\
\hline Menikah & 12 & 75 & 15 & 93,8 \\
\hline Belum/Cerai & 4 & 25 & 1 & 6,2 \\
\hline \multicolumn{5}{|l|}{ Pekerjaan } \\
\hline Tidak bekerja & 8 & 50 & 6 & 37,5 \\
\hline Bekerja & 8 & 50 & 10 & 62,5 \\
\hline \multicolumn{5}{|l|}{ Penghasilan } \\
\hline$<1$ Juta/bl & 6 & 37,5 & 5 & 31,2 \\
\hline 1-2 Juta/bl & 4 & 25 & 3 & 18,8 \\
\hline$>2$ Juta/bl & 6 & 37,5 & 8 & 50 \\
\hline Jumlah & 16 & 100 & 16 & 100 \\
\hline
\end{tabular}

Berdasarkan tabel 1. dapat dijelaskan bahwa pasien gagal ginjal kronis pada kelompok intervensi dan kelompok kontrol sebagian besar berusia $>41$ tahun dan berpendidikan tamat SD. Karakteristik jenis kelamin pada kedua kelompok mempunyai jumlah yang sama, laki-laki sebanyak 11 orang $(68,8$ $\%$ ) dan perempuan sebanyak 5 orang $(31,2 \%)$. Mayoritas responden sudah menikah, kelompok intervensi $75 \%$ dan kelompok kontrol 93,8 \%. Berdasarkan kategori pekerjaan, pada kelompok intervensi yang bekerja sebanyak $50 \%$, sedangkan kelompok kontrol 62,5\%. Tingkat penghasilan responden pada kelompok intervensi antara penghasilan $<1$ juta/bulan dan > 2 juta/bulan masing-masing berjumlah 6 orang $(37,5$ $\%)$. Sedangkan pada kelompok kontrol, sebagian besar mempunyai penghasilan $>2$ juta/bulan yaitu sebanyak 8 orang $(50 \%)$.

Tabel 2. Distribusi Psychosocial adjustment sebelum dan sesudah terapi self management.

\begin{tabular}{lcccc}
\hline No & $\begin{array}{l}\text { Pre- } \\
\text { intervensi }\end{array}$ & $\begin{array}{l}\text { Post- } \\
\text { intervensi }\end{array}$ & $\begin{array}{l}\text { Pre- } \\
\text { kontrol }\end{array}$ & $\begin{array}{l}\text { Post- } \\
\text { kontrol }\end{array}$ \\
\hline 1 & 109 & 140 & 95 & 110 \\
2 & 112 & 143 & 98 & 105 \\
3 & 99 & 144 & 88 & 92 \\
4 & 102 & 146 & 95 & 99 \\
5 & 90 & 141 & 88 & 91 \\
6 & 120 & 154 & 100 & 110 \\
7 & 118 & 148 & 86 & 90 \\
8 & 140 & 165 & 87 & 92 \\
9 & 110 & 147 & 95 & 92 \\
10 & 100 & 149 & 88 & 91 \\
11 & 98 & 143 & 86 & 90 \\
12 & 91 & 141 & 88 & 92 \\
13 & 89 & 140 & 92 & 96 \\
14 & 92 & 119 & 105 & 112 \\
15 & 90 & 124 & 108 & 116 \\
16 & 90 & 125 & 140 & 136 \\
\hline & $\bar{x}: 103,12$ & $\bar{x}: 141,81$ & $\bar{x}: 96,19$ & $\bar{x}: 100,88$ \\
\end{tabular}

Berdasarkan tabel 2. dapat dijelaskan skor pre-test pada kelompok intervensi mempunyai nilai rata-rata $(\mathrm{x})$ : 103, 12 dengan nilai minimal 89 dan nilai maksimal 140. Setelah dilakukan terapi self management, skor post-test didapatkan nilai rata-rata $(\mathrm{x})$ : 141,81 dengan nilai minimal 119 dan nilai maksimal 165. Pada kelompok kontrol didapatkan nilai rata-rata $(\mathrm{x})$ : 96, 19 dengan nilai minimal 86 dan nilai maksimal 140 pada kegiatan pre-test. 
Selanjutnya, nilai post-test didapatkan rata-rata $(x)$ : 100,88 dengan nilai minimal 90 dan nilai maksimal 136 .

Tabel 3. Pengaruh self management terhadap psychosocial adjustment pada pasien dengan penyakit ginjal kronis.

\begin{tabular}{lccc}
\hline $\begin{array}{l}\text { Psychosocial } \\
\text { adjustment }\end{array}$ & $\mathrm{n}$ & $\begin{array}{c}\text { Median } \\
\text { (minimum- } \\
\text { maksimum) }\end{array}$ & $p$ \\
\hline $\begin{array}{l}\text { Sebelum self } \\
\text { management }\end{array}$ & 16 & $99,5(89-140)$ & 0,000 \\
$\begin{array}{l}\text { Setelah self } \\
\text { management }\end{array}$ & 16 & $143(119-165)$ & \\
\hline
\end{tabular}

Hasil uji normalitas shapiro-wilk didapatkan hasil $p=0,000$ sehingga didapatkan kesimpulan distribusi data tidak normal karena nilai $p<0,05$. Hasil uji wilcoxon didapatkan hasil $p$ value < 0,05 , maka hipotesa Ha diterima, berarti variabel terapi self management berpengaruh terhadap kemampuan psychosocial adjustment pasien penyakit ginjal kronis, atau dengan kata lain hipotesa penelitian ini diterima.

\section{PEMBAHASAN}

Hasil penelitian ini menunjukkan bahwa pada karakteristik usia responden yang mengalami penyakit ginjal kronis didominasi oleh usia > 41 tahun. Hasil penelitian serupa didapatkan pada penelitian yang dilakukan oleh Tjekyan (2012) menyatakan angka kejadian penyakit ginjal kronis akan meningkat seiring dengan bertambahnya usia. Penelitian tersebut melibatkan 300 responden pasien penyakit ginjal kronis dimana sebanyak 231 responden (77\%) berusia lebih dari 40 tahun mengalami masalah ginjal kronis dengan rincian sebagai berikut $23 \%$ pada usia $40-49$ tahun, $27,3 \%$ pada usia 50 - 59 tahun dan $25,1 \%$ pada usia $\geq 60$ tahun.
Penyakit ginjal kronis sebenarnya dapat terjadi pada semua tingkat usia. Namun, bila diidentifikasi lebih detail terjadi penyakit ginjal kronis dapat terjadi sering dengan bertambahnya usia seseorang, disamping ada beberapa faktor yang mempengaruhinya. Di Indonesia, penyakit ginjal kronis diperburuk karena adanya proses infeksi yang sering terjadi sehubungan dengan penyakit-penyakit yang ada pada daerah dengan iklim tropis. Kondisi ini berbeda dengan di negara maju, misalnya di Amerika Serikat, penyakit ginjal kronis $47 \%$ terjadi pada pasien berusia lebih dari 60 tahun. Penyakit ginjal kronis tersebut disebabkan oleh faktor perilaku dan gaya hidup terutama dari asupan makanan (Levey, 2007). Penyebab lainnya adalah adanya gangguan metabolik seperti diabetes melitus, hipertensi, glomerulonefritis dan penyakit lainnya yang berhubungan dengan obstruksi.

Selanjutnya, berdasarkan karakteritik jenis kelamin. Pada penelitian ini responden pria lebih banyak mengalami penyakit ginjal kronis dibanding perempuan dengan rasio pria sejumlah 11 orang $(68,8 \%)$ dan perempuan $5(31,2 \%)$ pada kelompok intervensi. Hasil penelitian yang dilakukan oleh Lathifah (2016) menyebutkan 80 pasien dengan penyakit ginjal kronis yang dirawat dan menjalani terapi hemodialisis di RSUD Moewardi, lebih banyak pria daripada wanita baik pada kelompok intervensi maupun kelompok kontrol. Pada kelompok intervensi jumlah pria sebanyak 26 $(65 \%)$ dan 14 wanita $(35 \%)$, sedangkan pada kelompok kontrol terdapat 24 pria $(60 \%)$ dan 16 wanita $(40 \%)$.

Tingkat pendidikan responden pada kelompok intervensi dalam penelitian ini lebih didominasi oleh 
pendidikan tamatan SD dan tamatan SLTA masing-masing ada 6 orang $(37,5 \%)$, dan pada kelompok kontrol sebagian besar responden tamatan SD sebanyak 8 orang $(50 \%)$. Pendidikan adalah salah satu faktor yang berpengaruh terhadap pengetahuan, sikap dan tindakan yang dimiliki oleh individu (Notoatmojo, 2003). Pengetahuan yang baik dapat sebagai stimulus terjadinya perubahan sikap dan melandasi individu untuk melakukan tindakan dalam penyesuaian diri terhadap sakit yang dialami. Penyesuaian diri tersebut merupakan manifestasi kemampuan individu dalam melakukan psychosocial adjustment terhadap perubahan status kesehatannya.

Penelitian yang dilakukan oleh Sitiaga (2015) mengidentifikasi 31 pasien gagal ginjal kronis dengan karakteristik latar belakang pendidikan dibagi dalam dua kategori yaitu pendidikan dasar dan pendidikan lanjut. Ada 23 responden $(74,19 \%)$ dengan kategori pendidikan dasar dan 8 responden $(25,81 \%)$ dengan kategori pendidikan lanjut. Hasil penelitian tersebut menyatakan bahwa sebanyak 18 responden (58,07\%) mempunyai pengetahuan yang baik tentang penyakit ginjal kronis dan terapi yang harus dijalaninya termasuk program pengaturan pola makan (diet) dan sebanyak 13 responden yang mempunyai pengetahun kurang baik. Walaupun ada kesenjangan hasil penelitian, namun belum tentu individu dengan pendidikan rendah akan berimplikasi terhadap pengetahuan yang rendah pula dan juga sebaliknya.

Status pernikahan yang dimiliki oleh pasien ginjal kronis dapat dijadikan salah satu aspek pendukung dalam terapi self management, karena besar atau tidaknya dukungan yang diberikan oleh pasangan hidup akan berkontribusi terhadap kemampuan mereka dalam melakukan adaptasi secara psiko-sosial. Individu akan merasa kuat menghadapi penyakit dan menjalani terapi hemodialisis. Dukungan dari pasangan hidup dapat berupa motivasi, penghargaan atau reinforcement positif, perhatian dan mencari jalan keluar terhadap masalah yang dihadapinya.

Hasil penelitian ini berbeda dengan penelitian sebelumnya yang dilakukan oleh Rukmaliza (2017) yang menyatakan tidak ada hubungan antara status menikah $(79,4 \%)$ dengan kualitas hidup pasien gagal ginjal kronis. Penelitian ini hanya mengidentifikasi hubungan karakteristik responden dengan kualitas hidup yang dimiliki. Sehingga, peran perawat yang bekerja di ruang hemodialisis sangat penting untuk mendukung pasien gagal ginjal kronis selama menjalani terapi hemodialisis.

Hasil penelitian ini menunjukkan bahwa status pekerjaan responden baik yang bekerja atau tidak bekerja pada kelompok intervensi mempunyai jumlah yang sama masing-masing 8 responden $(50 \%)$. Sedangkan pada kelompok kontrol, responden dengan status bekerja lebih banyak dari pada yang tidak bekerja dengan jumlah 10 responden $(62,5 \%)$ dan yang tidak 6 responden (37,5\%). Demikian juga penelitian yang dilakukan oleh Purwati dan Wahyuni (2016) mengidentifikasi 103 responden dengan penyakit gagal ginjal kronis yang menjalani terapi hemodialisa di RS Gatoel Mojokerto dimana sebanyak 29 orang $(28,2 \%)$ dengan status bekerja dan 74 orang $(71,8 \%)$ dengan status tidak bekerja. Namun, dalam penelitian tersebut tidak menjelaskan hubungan status pekerjaan dengan kualitas hidup pasien gagal ginjal kronis. Dalam penelitian ini, Purwati dan 
Wahyuni (2016) menyatakan faktor yang mempengaruhi kualitas hidup pasien gagal ginjal kronis yaitu jenis kelamin, tingkat pendidikan dan status pernikahan.

Hasil penelitian ini mendukung penelitian sebelumnya yang dilakukan oleh Hartini (2016) yang meneliti 134 pasien penyakit gagal ginjal kronis di RS Moewardi menyatakan pasien yang mempunyai kecukupan ekonomi akan mampu menyediakan segala fasilitas yang diperlukan selama menjalani terapi hemodialisis di rumah sakit dan mampu memenuhi kebutuhan hidup hariannya. $\mathrm{Hal}$ ini tentunya berbeda dengan pasien dengan penghasilan rendah, dimana mereka akan memenuhi kesulitan dalam menenuhi kebutuhan hidupnya temasuk dalam memanfaatkan fasilitas pelayanan kesehatan. Pada penelitian tersebut juga mengemukakan 58 responden $(43,3 \%)$ dengan penghasilan rendah $<1.425 .000$ per bulan menderita penyakit gagal ginjal kronis lebih besar dari pada mereka yang berpenghasilan sedang dan tinggi.

Selanjutnya, hasil penelitian ini juga menyatakan bahwa terdapat peningkatan kemampuan psychosocial adjustment pasien dengan penyakit ginjal kronis setelah mengikuti program terapi self management. Demikian juga hasil penelitian yang dilakukan Lorig dan Holan (2003) menyatakan pasien dengan terapi hemodialisis berupaya melakukan penyesuaian diri terhadap kondisi sakitnya dimana tingkat penyesuaian diri terbanyak dalam kategori sedang yaitu $47 \%$, tinggi sebanyak $33 \%$ dan tingkat penyesuaian rendah $20 \%$.

Ada tiga kategori yang harus dilakukan pada terapi self management menurut Green (2012) yaitu terapi harus berfokus pada kebutuhan sakit yang dialami oleh pasien, melibatkan sumber daya yang dimiliki oleh pasien dan membantu pasien untuk terbiasa hidup dengan kondisi penyakit kronis. Terapi self management atau dikenal dengan istilah pengelolaan diri ini merupakan salah satu model terapi dalam keperawatan jiwa yaitu cognitive behavior therapy (CBT). Terapi manajemen diri (self management) diupayakan agar pasien dengan masalah utama penyakit ginjal kronis dapat melakukan perencanaan, pemusatan perhatian dan evaluasi terhadap aktivitas yang harus dilakukan sehubungan dengan perubahan status kesehatan aktual yang dialaminya.

Terapi self management dewasa ini sangat penting untuk dilakukan pada pasien penyakit ginjal kronis yang menjalani hemodialisis. Hal ini seiring dengan perubahan pola pengobatan atau terapi yang harus dijalani oleh pasien. Maka, terapi self management bagi pasien penyakit ginjal kronis yang menjalani terapi hemodialisa dalam prosesnya dapat mengarahkan pasien untuk melakukan perubahan terhadap perilakunya sendiri dengan suatu teknik terapeutik yang dilakukan oleh perawat hemodialisa melalui edukasi dan SEFT therapy.

Menurut Green (2012) terdapat beberapa faktor yang berpengaruh dalam pemberian terapi self management pada penyakit kronis seperti penyakit ginjal kronis. Pertama, faktor demografi seperti kondisi atau status sosial ekonomi dan budaya. Kedua, faktor klinik seperti adanya penyakit penyerta yang dialami pasien penyakit ginjal kronis (comorbidities), dan kompleksitas pengobatan yang harus dijalani pasien. Ketiga, faktor sistem seperti kualitas hubungan dan komunikasi dengan pemberi pelayanan kesehatan. Faktor-faktor tersebut sangat mempengaruhi kemampuan pasien dan 
motivasi yang dimilikinya untuk melakukan penyesuaian diri secara psikososial atau psychosocial adjustment. Selain itu pengalaman masa lalu dalam menjalani pengobatan sehubungan dengan penyakitnya, turut berkontribusi dalam keberhasilan terapi self management.

\section{KESIMPULAN}

Karakteristik responden dalam penelitian ini didominasi oleh usia $>41$ tahun, $\mathrm{n}$ latar belakang pendidikan tamat SD dan SLTA, status menikah, dan bekerja dengan mayoritas penghasilan $>2$ juta/bulan. Kemampuan psychosocial adjustment pasien penyakit ginjal kronis sebelum dilakukan intervensi (edukasi dan SEFT therapy) mempunyai nilai ratarata (X) PAIS: 103,12 menjadi meningkat setelah intervensi dengan nilai rata-rata (x) PAIS: 141,81. Uji wilcoxon didapatkan $p$ value 0,000 maka dapat disimpulkan terdapat pengaruh self management terhadap kemampuan psychosocial adjustment pasien dengan penyakit ginjal kronis dimana $p$ value < 0,05 maka hipotesa penelitian ini diterima.

\section{SARAN}

Pasien dengan penyakit ginjal kronis harus mempunyai gaya hidup yang baik dan sehat selain tetap mengkonsumsi obat-obatan yang diresepkan oleh medis. Selanjutnya, keluarga sebagai support system bagi pasien dengan penyakit ginjal kronis diharapkan selalu mendampingi dan memberikan dukungan yang bersifat emosional, informatif dan saran selama pasien menjalani terapi hemodialisa. Demikian juga, perawat yang bekerja di ruang hemodialisa seharusnya mampu memberikan layanan edukasi tentang penyakit ginjal kronis, pengobatan dan penatalaksanannya serta layanan SEFT therapy bagi pasien dengan mengajarkan teknik tapping pada pada titik-titik tertentu untuk mengurangi perasaan stres, cemas dan depresi.

\section{UCAPAN TERIMA KASIH}

Ucapan terima kasih disampaikan kepada prodi Magister Keperawatan UNDIP, RSUD Banyumas, pasien yang menjalani terapi hemodialisa sehingga, penelitian ini dapat terselesaikan.

\section{DAFTAR PUSTAKA}

Muttaqin, A. (2009). Buku ajar keperawatan klien dengan gangguan sistem kardiovaskular dan hematologi. Jakarta: Salemba Medika.

Smart, et al. (2013) Exercise \& Sports Science Australia (ESSA) position statement on exercise and chronic kidney disease. Journal of Science and Medicine in Sport. Australia: Department of renal medicine Royal Brisbane and Women's Hospital.

Smeltzer. (2015). Keperawatan Medikal Bedah. Vol. 2, Jakarta: EGC.

Syamsir. (2008). Gagal ginjal. Jakarta: Gramedia.

Pernefri. (2003). Konsensus penatalaksanaan gagal ginjal. Jakarta: PRENEFRI.

Smeltzer, Suzanne C, dan Brenda G, Bare. (2002). Buku ajar keperawatan medikal bedah Brunner dan Suddarth. Edisi 8. Jakarta: EGC.

Nurani, V. M. dan Mariyanti, S. (2013). Gambaran makna hidup pasien gagal ginjal kronik yang 
menjalani hemodialisa. Jurnal Psikologi. 11. 1

Morton, PG, Fontaine, DK, Hudak, CM \& Gallo, BM. (2009). Critical care nursing - A holistic approach. edisi. 8. Philadelphia: Lippicott Williams and Wilkins.

Calhoun, J.F. \& Cocella, J.R. (1990). Psychology of adjusment and human relationship. New York: McGraw-Hill Publishing Co.

Chen, Tsai, Sun, Wu, Lee, Dan Wu. (2010). The impact of selfmanagement support on the progression of chronic kidney disease-A prospective randomized controlled trial. Oxford Journals. Oxford University Press.

Schena, F. P. (2011). Management of patients with chronic kidney disease.Intern Emerg Med:6 (Suppl 1) S77-S83.

Tjekyan, S. (2012) Prevalensi dan faktor risiko penyakit ginjal kronik di RSUP Moh. Hoesin Palembang. MKS. 46. No 4.

Levey, A.S. (2007). Chronic kidney disease progression. Tufts Open Course Ware, Tufts University School of Medicine, Boston United state.

Lathifah, A.U. (2016). Faktor risiko kejadian gagal ginjal kronis pada usia dewasa muda di RSUD Moewardi. Available from: http://eprints.ums.ac.id/45516/19 Inaskan\%20pubikasi.pdf diakses 26 Mei 2017.

Sitiaga, S. (2015). Hubungan tingkat pendidikan, pengetahuan dan dukungan keluarga dengan asupan protein pasien gagal ginjal kronis yang menjalani hemodialisa rawat jalan di RSUD Sukoharjo. Available from: http://eprints.ums.ac.id/40497/1/ PUBLIKASI\%20KARYA\%20ILMI AH.pdf diakses 26 Mei 2017.

Rukmaliza, T. (2013). Hubungan karakteristik individu dengan kualitas hidup pasien gagal ginjal kronik yang menjalani hemodialisis di RSUD Banda Aceh. Available from: http://etd.unsyiah.ac.id/index.php ?p=show detail\&id=9255 diakses 27 Mei 2017.

Purwati, H. \& Wahyuni, S. (2016). Hubungan antara lama menjalani hemodialisis dengan kualita hidup pasien gagal ginjal kronik di RS Gatoel Mojokerto. Available from: www.ejournal.stikeswilliambooth. ac.id/index.php/Kep/article diakses 27 Mei 2017

Hartini, S. (2016). Gambaran karakteristik pasien gagal ginjal kronis yang menjalani hemodialisa di RSUD Dr Moewardi. 2016 Sumber: http://eprints.ums.ac.id/44680/1/ nas $\% 20$ pub\%20jadi.pdf diakses 17 Mei 2017.

Lorig, K, \& Holan, H. (2003). Self management education: history, definition. Outcome and mechanisms.2003. Annals of Behavioral Medicine.26 (1): 50 62.

Green, et al. (2012). Processes of self management in chronic illness. Journal Nursing Scholarship. 44(2):

136-144. 